\title{
Cell-Free Protein Synthesis by Diversifying Bacterial Transcription Machinery
}

\author{
Marina Snapyan ${ }^{1,+}$, Sylvain Robin ${ }^{2}$, Garabet Yeretssian ${ }^{1}$, Michèle Lecocq ${ }^{1}$, Frédéric Marc ${ }^{2}$ \\ and Vehary Sakanyan $1,2,3, *$ (i)
}

1 UMR CNRS 6204, Faculté des Sciences et des Techniques, Université de Nantes, 44322 Nantes, France; marina.snapyan1@ulaval.ca (M.S.); gyeretssian78@gmail.com (G.Y.); michelle.lecocq@univ-nantes.fr (M.L.)

2 ProtNeteomix, 44322 Nantes, France; sylva_rob@yahoo.fr (S.R.); frederic.marc-kreucher@merckgroup.com (F.M.)

3 IICiMed, Faculté de Pharmacie, Université de Nantes, 44322 Nantes, France

* Correspondence: vehary.sakanyan@univ-nantes.fr; Tel.: +33-(0)632623998

+ Current address: CERVO Brain Research Center, Université Laval, Quebec City, QC G1J2G3, Canada.

Citation: Snapyan, M.; Robin, S.; Yeretssian, G.; Lecocq, M.; Marc, F.; Sakanyan, V. Cell-Free Protein Synthesis by Diversifying Bacterial Transcription Machinery. BioTech 2021, 10, 24. https://doi.org/ 10.3390/biotech10040024

Received: 19 June 2021

Accepted: 8 October 2021

Published: 14 October 2021

Publisher's Note: MDPI stays neutral with regard to jurisdictional claims in published maps and institutional affiliations.

Copyright: (C) 2021 by the authors. Licensee MDPI, Basel, Switzerland. This article is an open access article distributed under the terms and conditions of the Creative Commons Attribution (CC BY) license (https:// creativecommons.org/licenses/by/ $4.0 /)$.

\begin{abstract}
We have evaluated several approaches to increase protein synthesis in a cell-free coupled bacterial transcription and translation system. A strong pargC promoter, originally isolated from a moderate thermophilic bacterium Geobacillus stearothermophilus, was used to improve the performance of a cell-free system in extracts of Escherichia coli BL21 (DE3). A stimulating effect on protein synthesis was detected with extracts prepared from recombinant cells, in which the E. coli RNA polymerase subunits $\alpha, \beta, \beta^{\prime}$ and $\omega$ are simultaneously coexpressed. Appending a $3^{\prime}$ UTR genomic sequence and a T7 transcription terminator to the protein-coding region also improves the synthetic activity of some genes from linear DNA. The E. coli BL21 (DE3) rna::Tn10 mutant deficient in a periplasmic RNase I was constructed. The mutant cell-free extract increases by up to four-fold the expression of bacterial and human genes mediated from both bacterial pargC and phage pT7 promoters. By contrast, the RNase E deficiency does not affect the cell-free expression of the same genes. The regulatory proteins of the extremophilic bacterium Thermotoga, synthesized in a cell-free system, can provide the binding capacity to target DNA regions. The advantageous characteristics of cell-free systems described open attractive opportunities for high-throughput screening assays.
\end{abstract}

Keywords: cell-free protein synthesis; rpo genes coexpression; RNA polymerase; bacterial promoter; RNase I; protein overexpression

\section{Introduction}

A cell-free method for protein production has been successfully implemented by translating exogenously added nucleic acid into cell extracts of Escherichia coli [1]. Protein synthesis using the T7 phage transcriptional machinery increased protein yield and turned cell-free protein synthesis (CFPS) into a powerful approach for studying the proteomes of organisms with sequenced genomes without performing laborious gene cloning in living cells. The single subunit T7 RNA polymerase catalyzes mRNA synthesis with an elongation rate of 200 nucleotides per second, 4-8-fold higher than the multisubunit RNA polymerase of E. coli [2]. However, bacterial transcriptional machinery is conserved in distant bacteria [3], and its RNA polymerase can recognize various heterologous promoters, constituting a great advantage in the use of native transcriptional signals for in vitro gene expression studies. Similar CFPS systems have also been created using other bacterial species to achieve additional advantages over the E. coli system for detecting specific protein-protein interactions and identifying potential inhibitors of desired proteins [4,5].

Nine endonucleases have been identified and studied in E. coli, and the individual activity of these enzymes is responsible for mRNA degradation [6]. The protein yield depends not only on the rate of transcription but also on the stability of the target mRNAs 
synthesized, a question that is still obscure regarding cell-free systems. It is generally accepted that the fate of nascent mRNAs in bacteria depends on the activity of a multiprotein complex, the degradosome, in which RNase E plays a major role. Frameshift mutations, leading to the truncation of a C-terminal region of RNase E, decrease the RNase activity without affecting RNA processing and host cell growth [7]. Another enzyme, RNase I, is responsible for cleavage at sites located within full-length mRNAs [8,9]. The thermostable RNase I is in the periplasm of Gram-negative bacteria and accounts for more than $98 \%$ of total RNase activity in crude extracts assayed in the presence of EDTA [10]. The enzyme attacks also double-strand RNA structures formed in any type of cellular RNA at the increased ratio of enzyme/RNA. In view of the RNase I, which is liberated during the preparation of cell-free extracts, the question of the impact on mRNA degradation becomes important to improve the performance of CFPS.

We have shown that a pargC strong promoter (Figure 1A), preceding the Geobacillus stearothermophilus $\arg C J B D$ operon, can be applied to CFPS with extracts of E. coli [11]. A logical extension of this finding is to improve the pargC-mediated gene expression with the aim of exploiting it for future proteomic research. In this study, several approaches were tested to enhance protein productivity in a cell-free system. We improved the yield of both prokaryotic and eukaryotic proteins by the integration of strong bacterial and phage transcription signals into the cell-free extracts derived from mutant $E$. coli deficient in the RNase I activity.

$\mathbf{A}$

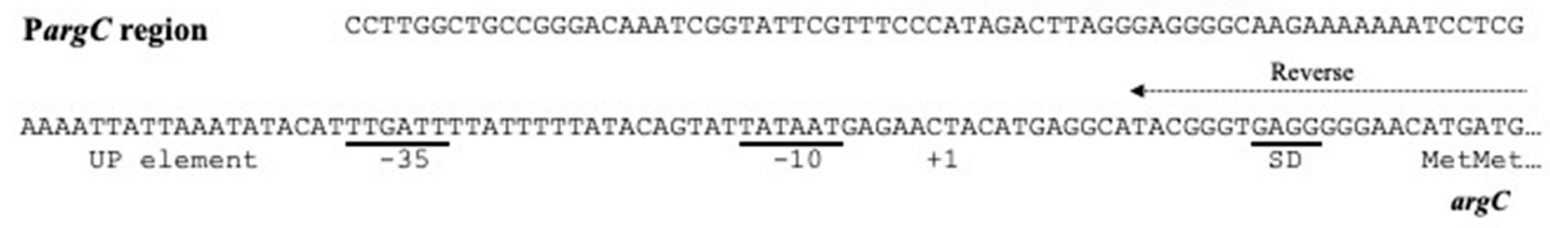

B
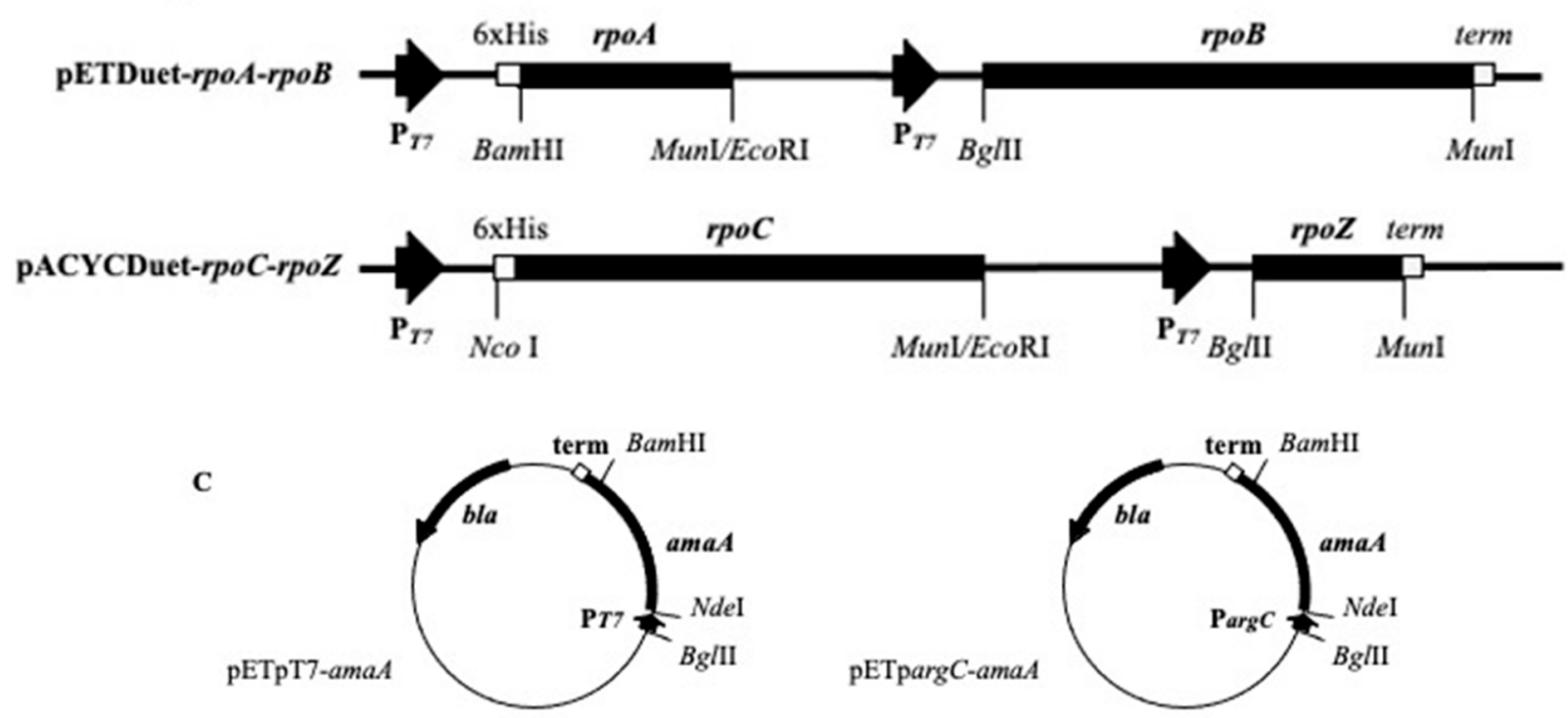

Figure 1. The G. stearothermophilus pargC region (A), the maps of recombinant plasmids carrying the E. coli rpo genes for core RNA polymerase (B) and the G. stearothermophilus amaA reporter gene $(\mathbf{C})$. The sequence of the used pargC region is shown; dotted arrows show positions of forward and reverse primers used for PCR. In a couple of pET-rpoA-rpoB and pACYC-rpoC-rpoZ plasmids, the rpoA and rpoC gene code for N-terminal His-tag. Abbreviations: UP for UP-element, SD for the site Shine-Dalgarno, term for T7 transcription terminator. 


\section{Materials and Methods}

\subsection{DNA Cloning}

The E. coli O157:H7 EDL933 rpo genes were cloned into two compatible vectors, pETDuet-1 and pACYCDuet-1 [12], each designed for the cloning and expression of two target genes (Merck, Lyon, France). The rpoA/rpoB and rpoC/rpoZ coding for couples of $\alpha / \beta$ and $\beta^{\prime} / \omega$ subunits were amplified by PCR using Taq DNA polymerase (Qiagen, CourtaBoeuf, Villebon-sur-Yvette, France) and inserted, respectively, into pETDuet-1 and pACYCDuet-1 vectors to provide coexpression of RNA polymerase subunits in the E. coli BL21 (DE3) strain (Figure 1).

The strain E. coli B (DE3) was used for gene expression assays. Chromosomal DNA of hyperthermophile bacteria Thermotoga maritima MSB8 and Thermotoga neapolitana DSM5068 was isolated as described previously [13]. Assuming a similarity to T. maritima [14], the T. neapolitana groESL chaperonin region was amplified using degenerate oligonucleotide primers 5'-GGAGGGATGGATGATGAARGTNA (forward) and 5' GAYTTYATHGAYCARCAYCCNGA (reverse) and inserted into pET19b between NdeI and BamHI restriction sites. The sequence groES was assigned EMBL accession AF275319. Other primers used for PCR amplification of T. maritima genes are described in Supplementary Table S1.

The rraA gene coding for the RNase E inhibitor protein RraA [15] was amplified by PCR from E. coli O157: H7 EDL 933 and inserted into expression vector pET28b+ between BamHI and HindIII restriction sites.

Comparison of cDNA and genomic DNA clones showed that the open reading frames of each of the NAT1 and NAT2 genes do not have introns, and the protein coding sequences are more than $80 \%$ identical [16]. Therefore, these genes were amplified by PCR on chromosomal DNA using forward primer 5'GATCATGGACATTGAAGCATATTTTGAAAG for NAT1 and NAT2 (initiation codon underlined) and reverse primers 5'CCTTATTCTAAATAGTAAAAAATCTATCAC for NAT1 and 5'CCTTATTCTAAATAGTAAGGGATCCATCACC for NAT2 (stop codon underlined). The genes were inserted into pET28b+ between NdeI and NotI restriction sites.

DNA concentration was determined by spectrophotometry and confirmed by comparing band intensity with a Smart Ladder reference DNA (Eurogentec, Liege, Belgium) after electrophoresis. The nucleotide sequences of PCR amplified genes were verified (Eurofins, Les Ulis, France).

\subsection{Construction of Linear DNA Templates}

The bacteriophage pT7 promoter and pargC promoter of G. stearothermophilus argC gene coding $N$-acetylglutamate-5-semialdehyde dehydrogenase [17] were used for driving the cell-free synthesis of target genes. A forward primer (5'-CATAGACTTAGGGAGGGGC) and a reverse primer (5'-ATGATGATGATGATGATGCATATGTTCCCCCTCACCCGT) were used to amplify the integral region covering the pargC promoter and the $\arg C$ initiation codon (see Figure 1A). The reverse primer was designed to introduce 6xHis codons, creating the N-terminal tag necessary for further purification of the protein RpoA ( $\alpha$ subunit of RNA polymerase) by affinity chromatography with Ni-NTA resin. The promoter pargC region was linked with the G. stearothermophilus gene amaA coding a $43 \mathrm{kDa} N$-acylamino acid amidohydrolase [18] or the T. maritima gntR 0439 gene coding for a $25 \mathrm{kDa}$ putative GntR regulator [19]. The connection of two DNA fragments was performed by the second-round PCR as described previously [20]. The quantity of DNA was quantified by lab-on-chip DNA 7500 assay kit with 2100 Bioanalyzer (Agilent Technologies, Les Ulis, France) by injecting a PCR product.

\subsection{P1 Transduction}

A bacteriophage $\mathrm{P} 1 \mathrm{cml}$ clr-100-mediated transduction of bacterial genes was performed at the multiplicity of infection equal to 0.1 [21]. The rna::Tn10 (kanamycin resistance) mutant gene [22] was transduced from the E. coli K12 DK533 strain to E. coli BL21 
(DE3) and E. coli BL21 Star (DE3) (rnaE131, deficient for RNase E). The transfer of a $\sim 2 \mathrm{~kb}$ rna::Tn10 DNA region was confirmed by PCR amplification using oligonucleotide primers 5'-ATGAAAGCATTCTGGCGTAAC and 5'-TTAATAACCCGCTTTATCAATC corresponding to the beginning and the end of the RNase I.

\subsection{Ribonuclease Assay}

The reaction was carried out at $37^{\circ} \mathrm{C}$ for 30 min with RNaseAlert Lab Test kit (Ambion, Berlin, Germany). Real-time fluorescence measurements were performed during incubation at excitation $490 \mathrm{~nm}$ and emission $520 \mathrm{~nm}$ with a fluorometer FP6500 (Jasco, Lisses, France) according to the supplier's recommendations. A relative RNase I activity was expressed in \% after $30 \mathrm{~min}$ incubation using the maximal activity detected in one of the extracts analyzed as a reference.

\subsection{Purification of Proteins and Western Blotting}

E. coli strains, in which T7 bacteriophage RNA polymerase synthesis is regulated by a lacUV5 inducible promoter, were grown in LB broth at 28 or $37^{\circ} \mathrm{C}$ to $\mathrm{OD}_{600} 0.5$ or 0.8 , and after the addition of $1 \mathrm{mM} \mathrm{IPTG}$, the growth was continued for $4 \mathrm{~h}$ more to express a given gene from a T7 promoter in pET-derived recombinant plasmids. Recombinant Histagged proteins were purified on a $\mathrm{Ni}^{+2}$-NTA resin with imidazole (Sigma, Saint-QuentinFallavier, France). To assess the level of synthesized RNA polymerase subunits in cells used for the preparation of S30 extracts, protein samples were separated with SDS-PAGE and analyzed by Western blot using for comparison the purified E. coli RNA polymerase (Epicentre Technologies, Thane, India). Nitrocellulose membranes with transferred proteins were incubated with 1:200 diluted monoclonal antibodies against $\alpha, \beta$ or $\beta^{\prime}$ (Neoclone, Madison, WI, USA) under standard conditions. Membranes were washed, incubated with Alexa Fluor 680-labeled goat anti mouse antibody (Eurogentec, Liege, Belgium) for $1.5 \mathrm{~h}$ and, after washing, were scanned with Odyssey scanner (Li-cor Biosciences, Bad Hamburg, Germany).

\subsection{Purification of E. coli RNA Polymerase Subunits from Living Cells}

We used the method of obtaining core enzyme RNA polymerase of $E$. coli by purifying inclusion bodies formed in cells carrying four cloned genes together, $r p o A, r p o B, r p o C$ and rpoZ [23]. Four subunits, $\alpha, \beta, \beta^{\prime}$ and $\omega$, which formed inclusion bodies due to overexpression in the same cells, were denatured with $6 \mathrm{M}$ guanidine chloride and renatured by dialysis in Tris- $\mathrm{HCl} 50 \mathrm{mM}$, pH 7.9, $\mathrm{KCl} 200 \mathrm{mM}, \mathrm{MgCl} 210 \mathrm{mM}, \mathrm{ZnCl}_{2} 10 \mathrm{mM}$, EDTA $1 \mathrm{mM}, \beta$-mercaptoethanol $5 \mathrm{mM}$, glycerol $20 \%$. The subunits were then purified by precipitation with ammonium sulfate followed by chromatography. It was found that the subunit $\beta^{\prime}$ is less present in the resulting purified sample, which can affect the stoichiometry of the subunits required for the formation of the core enzyme. The factor $\sigma^{70}$, cloned from $r p o D$ in His-tag fusion was added to reconstitute the holoenzyme of RNA polymerase. The analysis of the purified enzyme was performed using the "Protein 200 plus assay" on an Agilent 2100 bioanalyzer (Agilent Technologies, Les Ulis, France).

\subsection{Preparation of S30 Cell-Free Extracts}

Bacterial cell-free extracts were prepared by the method described previously [24] with modifications. Cells were grown at $37^{\circ} \mathrm{C}$ to OD 0.8 , harvested by centrifugation, washed twice thoroughly in ice-cold buffer containing $10 \mathrm{mM}$ Tris-acetate $\mathrm{pH} 8.2,14 \mathrm{mM} \mathrm{Mg}$ acetate, $60 \mathrm{mM} \mathrm{KCl}, 6 \mathrm{mM} \beta$-mercaptoethanol and then disrupted by French press (Carver, Belle Plaine, MN, USA) at 9 tones $(\approx 20,000 \mathrm{psi})$. The disrupted cells were centrifuged at $30,000 \times g$ at $4{ }^{\circ} \mathrm{C}$ for $30 \mathrm{~min}$, and the supernatant was centrifuged again. The clear lysate was added in a ratio of 1:0.3 to the preincubation mixture containing $300 \mathrm{mM}$ Tris-acetate at pH 8.2, 9.2 mM Mg-acetate, $26 \mathrm{mM}$ ATP, $3.2 \mathrm{mM}$ dithiothreitol, $3.2 \mathrm{mM} \mathrm{L-amino} \mathrm{acids}$ and incubated at $37^{\circ} \mathrm{C}$ for $80 \mathrm{~min}$. The mixed extract solution was centrifuged at $6000 \times \mathrm{g}$ at $4{ }^{\circ} \mathrm{C}$ for $10 \mathrm{~min}$, dialyzed against a buffer containing $10 \mathrm{mM}$ Tris-acetate $\mathrm{pH} 8.2,14 \mathrm{mM}$ 
Mg-acetate, $60 \mathrm{mM} \mathrm{K}$-acetate, $1 \mathrm{mM}$ dithiothreitol at $4{ }^{\circ} \mathrm{C}$ for $45 \mathrm{~min}$ with 2 changes of buffer, concentrated up to 4 times by dialysis against the same buffer containing $50 \%$ PEG-20,000, followed by additional dialysis without PEG. The obtained S30 cell-free extract was aliquoted and stored at $-80^{\circ} \mathrm{C}$.

\subsection{Cell-Free Protein Synthesis}

The batch-mode of cell-free synthetic reaction was carried out under the conditions described by Pratt [25] with some modifications. The standard premix contained $50 \mathrm{mM}$ Tris-acetate $\mathrm{pH}$ 8.2, $46.2 \mathrm{mM} \mathrm{K}$-acetate, $0.8 \mathrm{mM}$ dithiotreitol, $33.7 \mathrm{mM} \mathrm{NH} 4$-acetate, $12.5 \mathrm{mM}$ Mg-acetate, $125 \mu \mathrm{g} / \mathrm{mL}$ tRNA from E. coli (Sigma), $6 \mathrm{mM}$ mixture of CTP, GTP and TTP, $5.5 \mathrm{mM}$ ATP, $8.7 \mathrm{mM} \mathrm{CaCl} 2,1.9 \%$ PEG-8000, $0.32 \mathrm{mM}$ L-amino acids, $5.4 \mu \mathrm{g} / \mathrm{mL}$ folic acid, $5.4 \mu \mathrm{g} / \mathrm{mL}$ FAD, $10.8 \mu \mathrm{g} / \mathrm{mL}$ NADP, $5.4 \mu \mathrm{g} / \mathrm{mL}$ pyridoxin and $5.4 \mu \mathrm{g} / \mathrm{mL}$ paraaminobenzoic acid. The enzyme pyruvate oxidase was used to generate ATP via acetyl phosphate formation from pyruvate and inorganic phosphate [26] by addition of $32 \mathrm{mM}$ pyruvate in $6.7 \mathrm{mM} \mathrm{K}$-phosphate $\mathrm{pH} 7.5,3.3 \mathrm{mM}$ thiamine pyrophosphate, $0.3 \mathrm{mM}$ FAD and $6 \mathrm{U} / \mathrm{mL}$ pyruvate oxidase (Sigma). To express the cloned genes from T7 promoterdriven constructs, the T7 RNA polymerase (Promega, Charbonnières-les-Bains, France) was added to the reaction mixture. Circular plasmid DNA or linear PCR-amplified DNA was added to the premix containing all necessary L-amino acids except methionine, replaced by $10 \mu \mathrm{Ci}$ of [ $\alpha 35 \mathrm{~S}$ ]-L-methionine with specific activity $1000 \mathrm{Ci} / \mathrm{mmol}, 37 \mathrm{TBq} / \mathrm{mmol}$ (GE Healthcare, Parçay Mesley, France), and the reaction was initiated by adding E. coli cell-free extract followed by incubation at $37^{\circ} \mathrm{C}$ for $90 \mathrm{~min}$. The plasmid pET-pargC-8amaA [27] and pET-pT7-amaA have the same size between the ribosome binding site of promoters and the T7 terminator region, including the 8-nucleotide segment between the Shine-Dalgarno site and the initiation codon for translation. Similar conditions were used for protein synthesis with each cell extract, and the same volume was loaded into lanes for each given protein. Quantification of cell-free synthesized proteins was performed by counting the radioactivity of ${ }^{35}$ S-labeled protein bands with Phosphor Imager 445 SI (Molecular Dynamics, Chatsworth, CA, USA) or by comparing non radiolabeled protein bands with known reference proteins after coloration with EZBlue gel staining reagent (Sigma, Saint-Quentin-Fallavier, France).

\subsection{Mobility-Shift Assay}

Functional status of cell-free synthesized proteins was tested by mobility-shift assay using promoter-operator regions of T. maritima and E. coli. A putative promoter-operator region was obtained by PCR using IRDye-labeled primers (Supplementary Table S2) as described previously [28]. His-labeled proteins were diluted in binding buffer $10 \mathrm{mM}$ Tris- $\mathrm{HCl}$ (pH 7.5), $250 \mathrm{mM} \mathrm{KCl}, 5 \mathrm{mM} \mathrm{MgCl} 2,2.5 \mathrm{mM} \mathrm{CaCl}_{2}, 2.5 \%$ glycerol, $0.5 \mathrm{mM}$ DTT and then incubated labeled target DNA in the presence of a 100-fold of unlabeled sonicated herring sperm DNA at $37^{\circ} \mathrm{C}$ for $30 \mathrm{~min}$. Samples were loaded on a $2 \%(w / v)$ agarose gel prepared in TAE buffer ( $40 \mathrm{mM}$ Tris-base ( $\mathrm{pH} 8), 10 \mathrm{mM}$ sodium acetate, $1 \mathrm{mM}$ EDTA) and electrophoresed at room temperature at $12 \mathrm{~V} \mathrm{~cm}^{-1}$ for one hour. DNA fragments were transferred from gels onto a nylon membrane (Qiagen). The concentration of labeled DNAs was measured with a UV/VIS spectrometer (Perkin Elmer, Villebon-sur-Yvette, France) and by comparison of fluorescent DNA bands in an agarose gel.

\section{Results}

\subsection{Protein Synthesis in S30 Extracts Prepared from Cells Overexpressing RNA Polymerase Subunits}

The G. stearothermophilus pargC promoter possesses conserved -10 and -35 sites separated by a 17-bp spacer and an AT-rich UP element [29], (see Figure 1A). In order to gain higher gene expression from the parg $C$ promoter, we decided to increase the pool of the bacterial RNA polymerase in the reaction mixture by using the cell-free extracts in which core enzyme subunits were overexpressed. We constructed recombinant pDuet- 
based plasmids allowing T7 promoter-mediated coexpression of four genes coding for RNA polymerase $\alpha, \beta, \beta^{\prime}$ and $\omega$ subunits in E. coli cells after IPTG induction (see Figure 1B).

Analysis of the supernatant fraction from crude extracts of E. coli BL21 Star (DE3) (pETDuet-rpoA-rpoB/pACYCDuet-rpoC-rpoZ) showed that the protein bands corresponding to $\alpha, \beta$ and $\beta^{\prime}$ subunits were more intense than those of the plasmidless strain E. coli BL21 Star (DE3). Western blot analysis allowed us to assess the quantity of synthesized RNA polymerase subunits in a soluble fraction of cell extracts prepared from the same lysates (Figure 2). A weak band of the His-tagged $\alpha$ subunit was detected in noninduced cells; however, the amount of $\alpha$ subunit increased nearly 8-fold after IPTG induction. Meantime, the amount of both $\beta$ and $\beta^{\prime}$ increased about 2- and 2.5-fold, respectively.

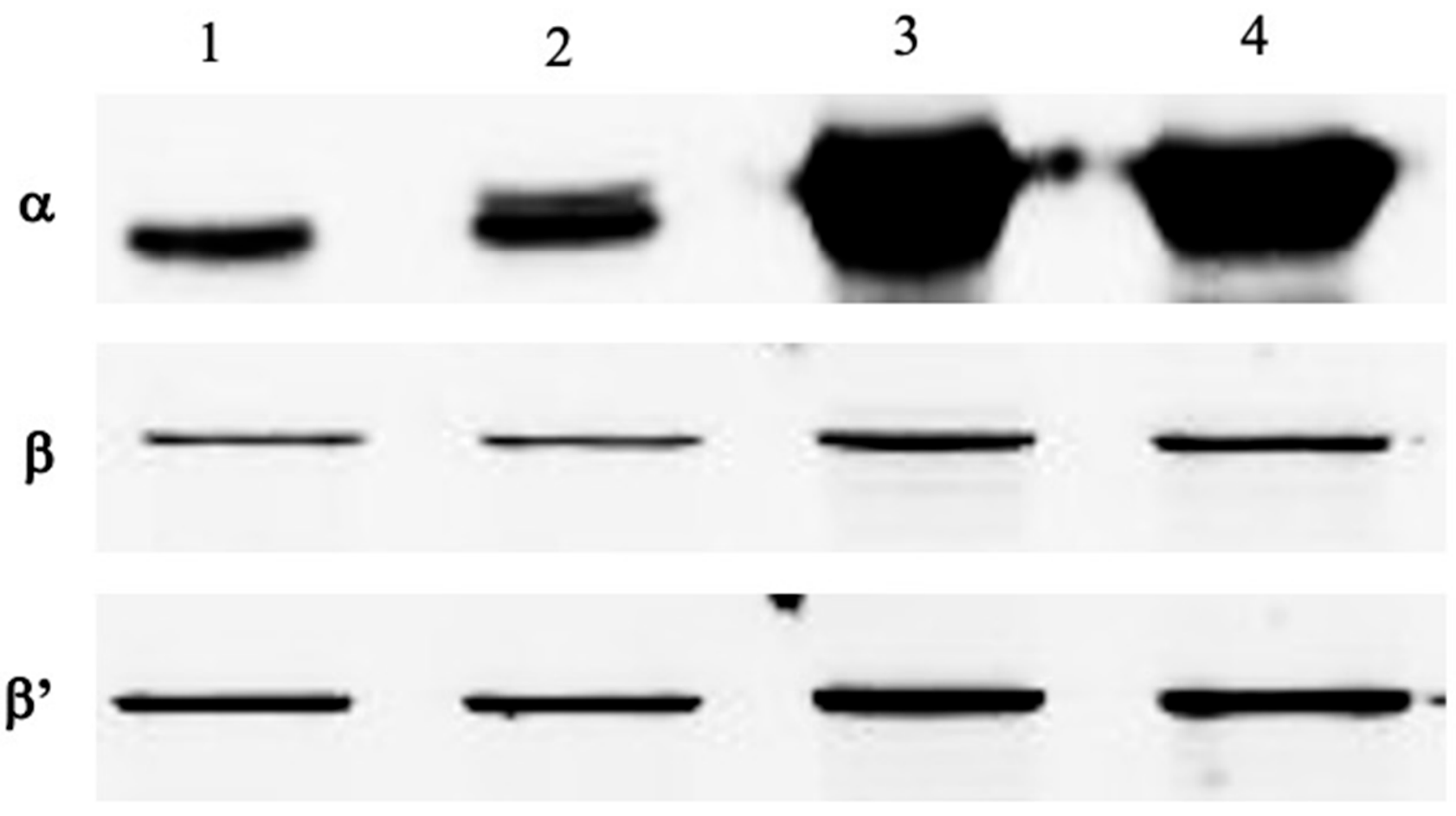

Figure 2. Western blot of RNA polymerase subunits $\alpha, \beta$ and $\beta^{\prime}$ in the supernatant of S30 extracts of cells without and with coexpression of genes rpoA, rроB, rроC and rpoZ. Detection of subunits was performed with the corresponding mAb. Lane 1, plasmidless E. coli BL21 Star (DE3) incubated with $1 \mathrm{mM}$ IPTG; lane 2, E. coli BL21 Star (DE3) (pETDuetrpoA-rpoB/pACYCDuet-rpoC-rpoZ) incubated without IPTG; lanes 3 and 4, E. coli BL21 Star (DE3) (pETDuet-rpoArpoB/pACYCDuet-rpoC-rpoZ) induced with IPTG at OD600 0.5 and 0.8 of cell growth, respectively.

To understand the reason for this difference, we performed a similar analysis of the insoluble fraction of the same extracts. It was observed that the majority of $\beta$ and $\beta^{\prime}$ subunits and, to a lesser extent, $\alpha$ subunits, precipitated in the pellet. Protein bands from cultures induced at $\mathrm{OD}_{600} 0.5$ and 0.8 have almost similar intensity, suggesting that the prolonged exponential growth before the IPTG-induction does not improve the yield of a soluble fraction of bacterial RNA polymerase subunits. Notably, the formation of an insoluble protein, probably in the form of $\beta^{\prime}$ subunit inclusion bodies, was also observed in living cells when four subunits of RNA polymerase were expressed together in the same cells. The addition of separately purified $\sigma$ factor likely improved the solubility and slightly increased yield of the holoenzyme RNA polymerase, comparable to a commercial enzyme (Figure 3). To increase the yield of RNA polymerase subunits, we recovered the various subunits by renaturation from inclusion bodies denatured in $6 \mathrm{M}$ guanidine chloride (Figures S1 and S2). However, the purified complex contained mainly $\alpha_{2} \beta$ and a low amount of $\beta^{\prime}$.

Next, we compared the parg $C$-mediated aminoacylase expression in cell-free extracts prepared from E. coli BL21 Star (DE3) (pETDuet-rpoA-rpoB / pACYCDuet-rpoC-rpoZ) cells 
using pETpargC-amaA circular plasmid DNA (Figure 1C) as a template at two concentrations. In two independent experiments, the amount of aminoacylase synthesized on circular plasmid DNA from the T7 phage promoter was quite close for DNA concentrations of 8 and $55 \mathrm{ng} / \mu \mathrm{L}$ (Figure 4). Meanwhile, the protein yield on this construct was almost double that of the pargC-amaA plasmid at $55 \mathrm{ng} / \mu \mathrm{L}$ DNA after IPTG-induction of cells at OD 0.8 (Figure 4B,D). We also compared both promoters in cell-free aminoacylase synthesis at OD 0.8 after subtracting the protein yield for E. coli BL21 Star (DE3) were incubated with IPTG. The pT7 promoter provided approximatively 5.3 and 3.8 times more protein at DNA concentrations of 8 and $55 \mathrm{ng} / \mu \mathrm{L}$, respectively, than the pargC-8 promoter at the same conditions.

We observed a relatively higher level of aminoacylase in the extracts from noninduced cells carrying the plasmids encoding the RNA polymerase subunits, compared to extracts from cells lacking these plasmids. This appears to reflect a leaky nature of the T7-based expression system used as proven by a weak band of the His-tagged RpoA in extracts from noninduced cells (lane 2 in Figure 2).

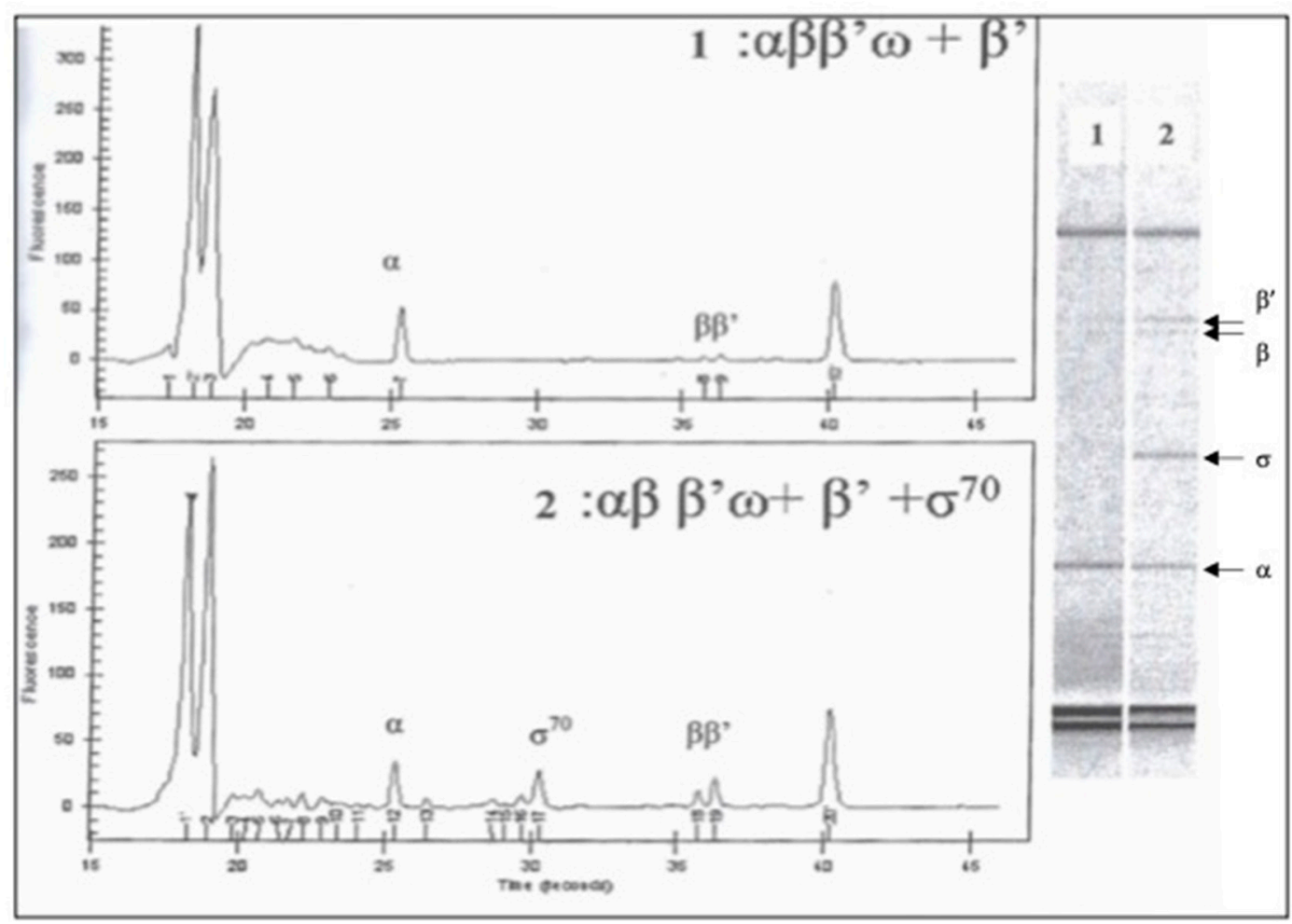

Figure 3. Analysis of E. coli RNA polymerase overexpressed in living cells. Detection of RNA polymerase subunits by capillary microelectrophoresis without $\sigma$ factor (1) and with added $\sigma 70$ factor (2). Factor $\sigma 70$ was purified separately and added to the purified proteins obtained in the soluble fraction.

Considering that the bacterial and phage promoters have an 8-nucleotide spacer between the ribosome binding site and the initiation codon for translation, as well as the same region of the T7 terminator, it can be concluded that the pargC promoter itself provides a relatively high yield of a given protein produced in a CFPS system.

\subsection{Extension of a $3^{\prime}$ Extremity of $m R N A$ Templates and T7 Transcription Terminator Increase CFPS}

The presence of stem-loop structures in a $3^{\prime}$ untranslated region ( $3^{\prime}$ UTR), recognized as transcription termination signals by RNA polymerase, protects nascent mRNAs from $3^{\prime}$ exonuclease degradation $[30,31]$. Therefore, to enhance the Parg $C$-mediated gene expression from linear DNA, we decided to enlarge the target gene mRNA template transcribed from 
PCR products by conserving genomic sequences located downstream of corresponding coding regions.

A

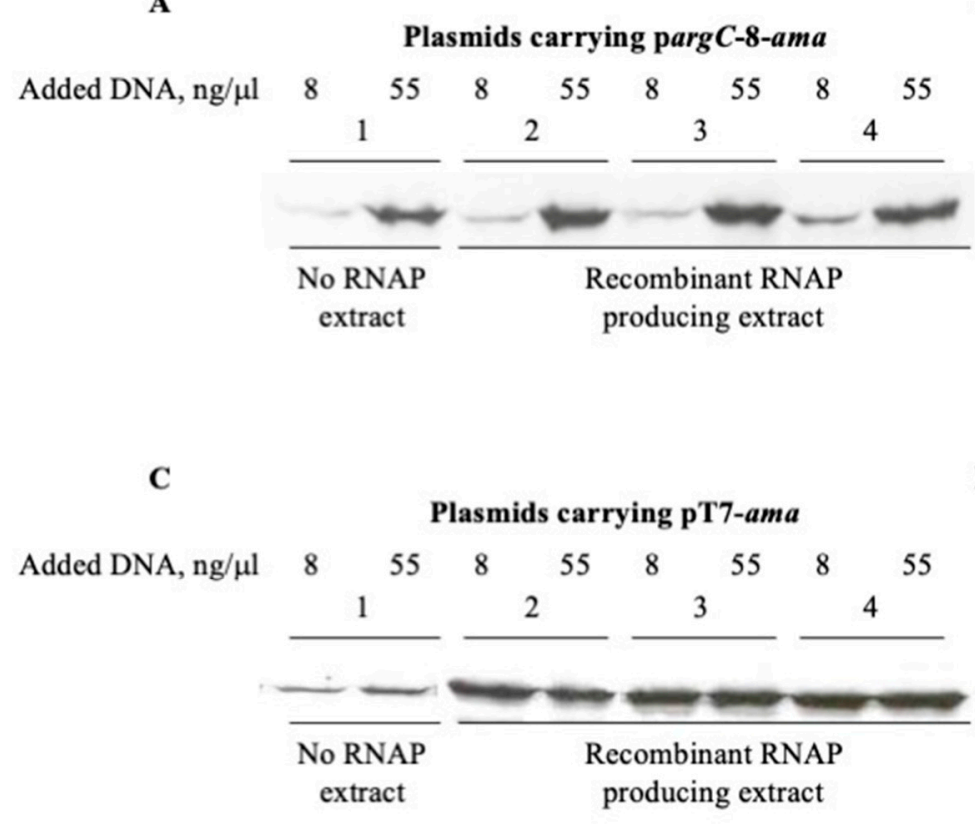

B

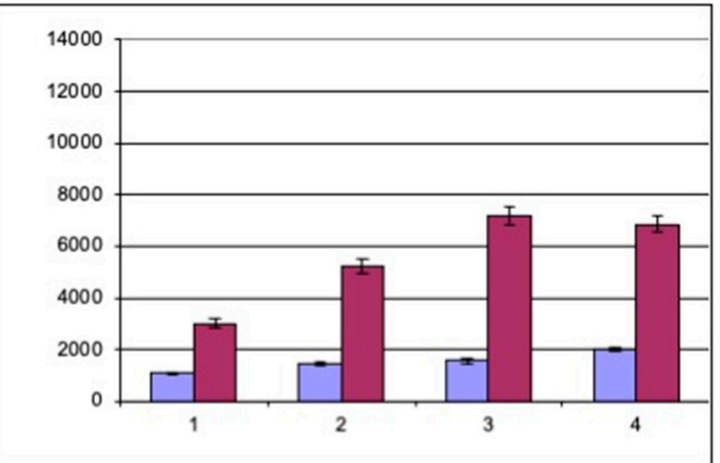

D

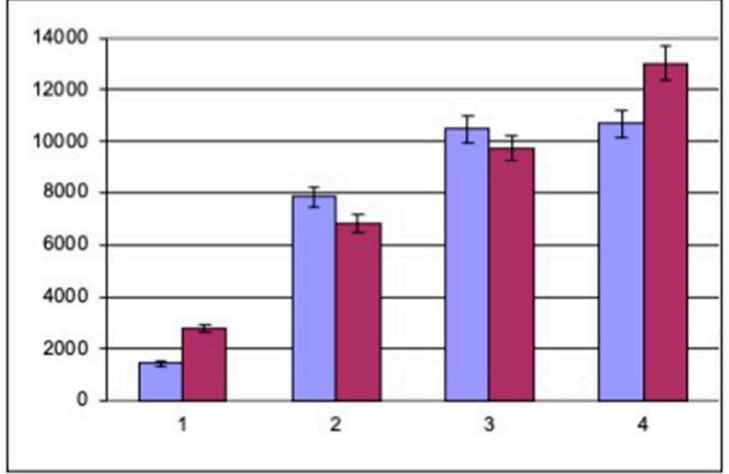

Figure 4. Comparison of aminoacylase synthesis under the control of pargC and pT7 promoters in cell-free extracts without and with induction of E. coli RNA polymerase $\alpha, \beta, \beta^{\prime}$ and $\omega$ subunits. DNA of plasmids pET-pargC-8-amaA (A,B) and pET-pT7-amaA (C,D) was added to the reaction mixture at concentrations of $8 \mathrm{ng} / \mu \mathrm{L}$ (color violet) and $55 \mathrm{ng} / \mu \mathrm{L}$ (color mauve). Lane 1 plasmidless E. coli BL21 Star (DE3) incubated with IPTG; lanes 2, noninduced E. coli BL21 Star (DE3) (pETDuet-rpoA-rpoB / pACYCDuet-rpoC-rpoZ); lane 3, E. coli BL21 Star (DE3) (pETDuet-rpoA-rpoB/ pACYCDuet-rpoC-rpoZ) induced with IPTG at $\mathrm{OD}_{600}$ 0.5; lane 4, E. coli BL21 Star (DE3) (pETDuet-rpoA-rpoB/ pACYCDuet-rpoC-rpoZ) induced with IPTG at $\mathrm{OD}_{600}$ 0.8. The incorporation of ${ }^{35} \mathrm{~S}$ methionine into the synthesized aminoacylase was assessed using a PhosphorImager. Histograms represent data from two experiments.

Linear DNA fragments, corresponding to G. stearothermophilus $\arg C$ and $a m a A$ genes and T. maritima gntR0439 gene, were amplified by PCR by conserving 3, 100 or $200 \mathrm{bp}$ sequences located downstream of the termination codon of each gene. A similar, rather high protein yield was found for GntR0439 from all three linear DNAs (Figure 5A) suggesting that the transcribed gntR0439 mRNA covering the only coding region is a good substrate for bacterial ribosomes to provide high protein productivity. By contrast, two other genes, $\arg C$ and especially amaA, required longer DNA templates to be translated into the corresponding polypeptides (see Figure $5 \mathrm{~A}$ ). If a 3 bp extension was enough to obtain an abundant band of a $38 \mathrm{kDa} N$-acetylglutamate-5-semialdehyde dehydrogenase encoded by $\arg C$, a longer $100 \mathrm{bp}$ genomic sequence was necessary to achieve a high synthesis of a $42 \mathrm{kDa}$ aminoacylase encoded by amaA. Further elongation of the respective regions located downstream had less effect on the expression of both genes. These data suggested that appending a 100-200 bp sequence downstream of target genes by PCR amplification from bacterial genomes is beneficial and could potentially be used to protect corresponding mRNAs from a ribonuclease attack.

We studied the effect of a well-characterized T7 phage stem-loop structure on the $a m a A$ reporter gene expression from pargC. Two linear DNA fragments were prepared, composed of the $\operatorname{parg} C$ region linked to the $G$. stearothermophilus amaA gene with its own $200 \mathrm{bp} \mathrm{3}$ ' UTR or connected to the same gene with a $48 \mathrm{bp}$ transcription terminator region of the pET3 vector used for the construction of pETparg-amaA (see Figure 1C). PCR amplified 
higher aminoacylase expression from linear DNA containing the phage stem-loop than from the analogous construct containing a $200 \mathrm{bp} 3^{\prime}$ UTR at DNA concentration $55 \mathrm{ng} / \mu \mathrm{L}$. Moreover, the pargC promoter module combined with the phage transcription terminator stimulated the aminoacylase productivity from a linear DNA to a level close to that of a circular plasmid DNA.

\subsection{Protein Synthesis Is Higher in RNase-I-Deficient Cell-Free Extracts}

The E. coli BL21 (DE3) host, naturally devoid of OmpT endoprotease and Lon protease [32], is better suited for CFPS [33]. The mutation rnaE131 in E. coli BL21 Star (DE3) leading to the formation of a C-terminal truncated RNase E, provides higher expression in cells of cloned genes transcribed from strong T7 phage promoters [34]. Considering that the activity of endoribonuclease RNase I could determine the stability of messages, it was tempting to assess the contribution of this enzyme to the protein production in cell-free extracts of an RNase I-deficient mutant (rna::Tn10).

Mutant strains deficient in RNase E (rnaE131), RNase I (rna::Tn10) and RNase E/RNase I activities were first compared in their endoribonuclease activity with parent strains using commercial substrate from Ambion. The crude lysates of the mutant rna::Tn10 exhibited more than two-fold lower activity (Table 1). Meantime, no difference was detected in crude extracts of wild-type $r n a E^{+}$and mutant rnaE131 cells, suggesting that RNase E does not hydrolyze the used substrate. The endoribonuclease activity remained almost at the same ratio in crude and cell-free extracts prepared from lysates of wild type $r n a^{+}$and mutant $r n a^{-}$cells.

Next, we compared cell-free synthesis of prokaryotic and eukaryotic proteins using the extracts prepared from RNase I-deficient and -proficient strains. The reaction was initiated by adding T7 RNA polymerase to the mixture containing a T7 promoter expression plasmid carrying bacterial genes amaA, groES and $r a A$ or human genes nat1 and nat2. Two independent preparations of S30 extracts were tested and gave similar positive results regarding the effect of RNase I deficiency. Indeed, autoradiography of gels clearly showed that protein bands were stronger with the extracts of E. coli BL21 (DE3) rna::Tn10 and E. coli BL21 Star (DE3) rna::Tn10 rnaE131 mutant strains than with the extracts of the respective rna+ hosts (Figure 5B). As judged from the measurement of the incorporated [ $\alpha 35 S$ S]-L-methionine, the extracts of RNase I-deficient cells provided 2-4-fold higher yields of the tested proteins, and this difference was the most pronounced for the bacterial GroES chaperone.

The amaA gene expression was also evaluated with pargC-amaA DNA in S30 extracts of RNase I-proficient and -deficient strains. The pargC promoter provided almost two-fold lower yield of aminoacylase than the pT7 promoter, as estimated by relative incorporation of a radioactive methionine into the protein. However, an increase in protein synthesis was again detected in the extracts of both rna::Tn10 and rnaE131 rna::Tn10 strains (see Figure 5B), suggesting that a positive effect of the RNase I deficiency is not dependent on the rate of mRNA synthesis in cell-free extracts. Surprisingly, no difference was detected in the yield of bacterial or human proteins synthesized in S30 extracts of $r n a^{+}$and rnaE131 bacteria, suggesting that the corresponding mRNAs are not susceptible to cleavage by RNase E. 

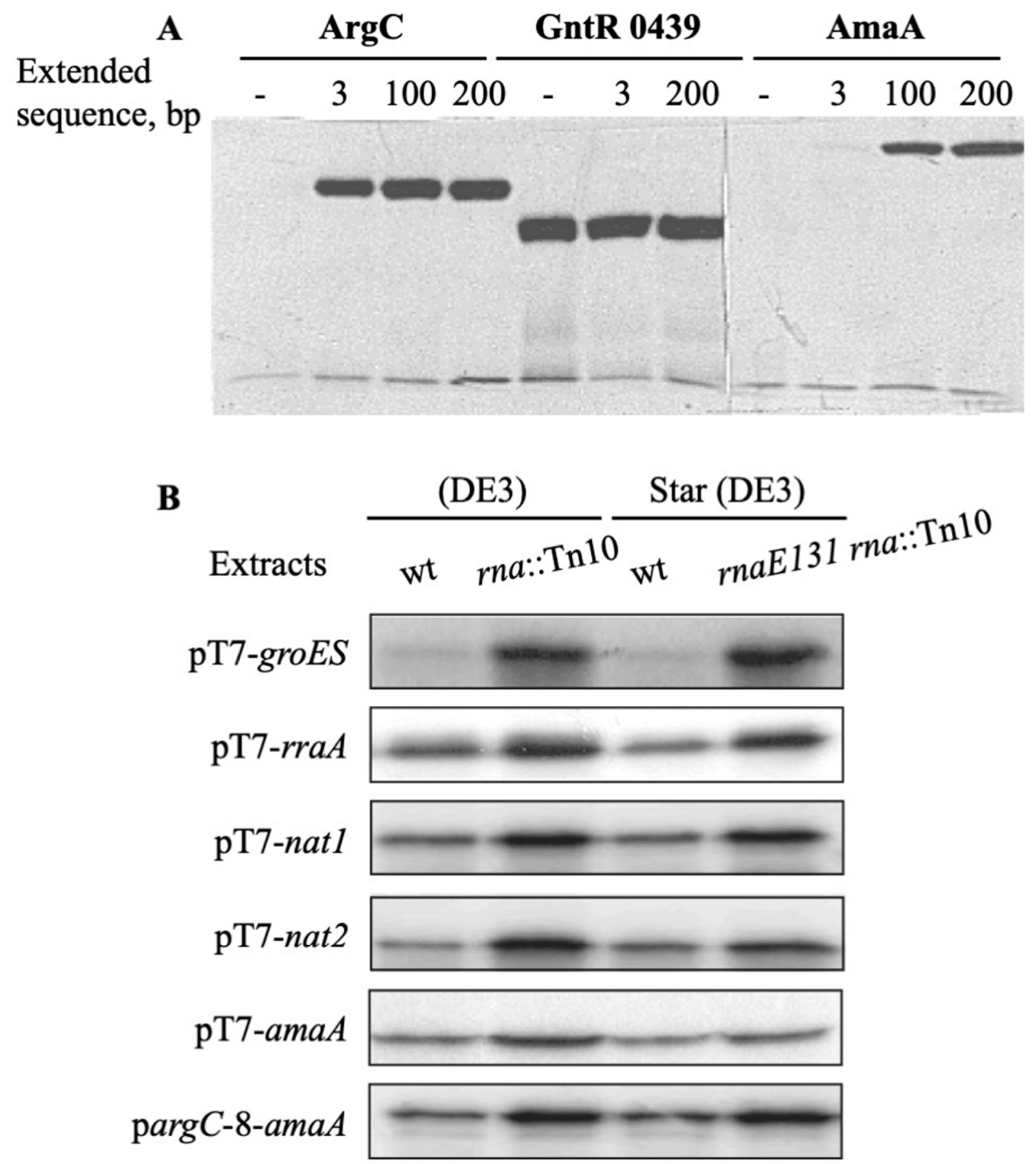

Figure 5. Effect of $3^{\prime}$-UTR extension on the pargC-promoted gene expression and protein production in wild-type and mutant RNase I (rna::Tn10) and RNase E (rnaE131) strains of E. coli. (A)—Lanes 1, 2, 3 and 4: G. stearothermophilus argC DNA, respectively, without and with an extended 3, 100 or 200 bp genomic sequence; lanes 5, 6 and 7: T. maritima gntR 0349 DNA, respectively, without and with an extended 3 or 200 bp genomic sequence; lanes 8, 9, 10 and 11: G. stearothermophilus amaA DNA, respectively without and with an extended 3, 100 or 200 bp genomic sequence. (B)-The T. neapolitana groES, E. coli rraA, human nat1 and nat2 genes were expressed from pT7 promoter in pET-pT7- $x$ plasmids ( $x$-any gene); and G. stearothermophilus amaA gene was expressed on pETpT7-amaA and pETpargC-amaA plasmids. Lanes 1-4, with S30 extracts of E. coli BL21 (DE3), E. coli BL21 (DE3) rna::Tn10, E. coli BL21 Star (DE3) rnaE13 and E. coli BL21 Star (DE3) rna::Tn10 rnaE131 strains, respectively. The sample volume used for analysis with pargC-8-amaA was twice that of plasmid pT7-8-amaA. Similar results were obtained in two assays. 
Table 1. Endoribonuclease activity in engineered E. coli strains.

\begin{tabular}{ccc}
\hline \multirow{2}{*}{ RNase Status } & \multicolumn{2}{c}{ Relative Endoribonuclease Activity (\%) } \\
\cline { 2 - 3 } & Crude Extracts & S30 Extracts \\
\hline BL21 (DE3) & 100 & 100 \\
BL21 (DE3) rna::Tn10 & 42 & 51 \\
BL21 Star (DE3) (it is rnaE131 strain) & 113 & 92 \\
BL21 Star (DE3) rnaE131 rna::Tn10 & 38 & 48 \\
\hline
\end{tabular}

\subsection{DNA-Protein Interaction in Cell-Free System}

The production of a functionally active protein in a cell-free system is an important criterion for the quality of the developed method. In this study, we evaluated the interaction of synthesized regulatory proteins in binding ability to a target DNA. Similar DNA-binding sequences in evolutionary distant bacteria are indicative of the resemblance between regulatory systems. Therefore, in the absence of adequate information on protein-DNA interactions, we tested our cell-free system using heterologous combination of interaction partners.

Three proteins belonging to Gnt, $\mathrm{Xyl}$ and Lac families of T. maritima putative regulators were cell-free synthesized and probed to IRDye-labeled operator sequences of E. coli, namely gntKo [35], xylFo [36] and lacIo [37]. Moreover, the cell-free synthesized T. neapolitana ArgR repressor was also probed to $\operatorname{argRo}$ DNA carrying a regulatory region of the same bacterium.

Mobility-shift analysis revealed that target DNAs bind to two proteins, T. neapolitana ArgR and T. maritima Gnt 0439 evidenced by the formation of clear retarding bands in the agarose gel (Figure 6). The putative laclo operator binding is likely to occur also with Lac 1856 as shown by a decrease in the protein band intensity in the presence of the target DNA. By contrast, no DNA binding was detected for the Xyl 0808 protein, suggesting that heterologous DNA from $E$. coli is not an interaction partner with the hyperthermophile protein. These results indicated that at least some of the transcriptional regulation proteins synthesized in the cell-free system are correctly folded to bind to target DNA probes.
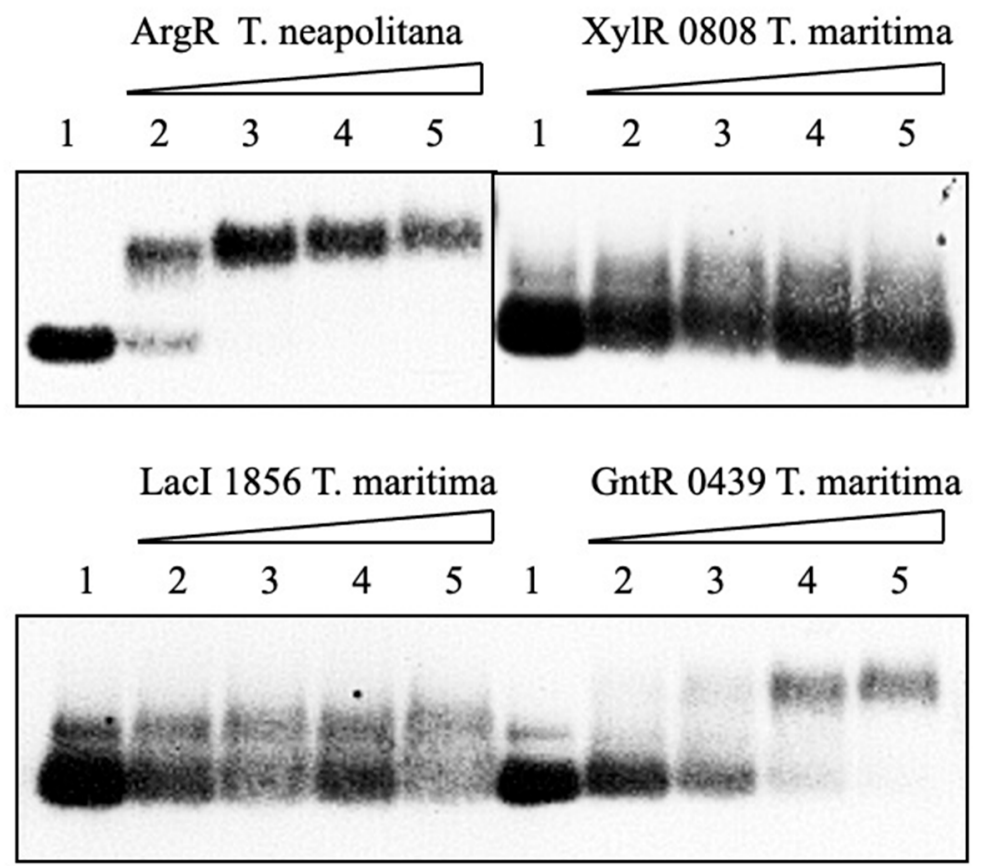

Figure 6. Gel-shift analysis of T. neapolitana and E. coli DNA operator regions binding to cell-free synthesized T. neapolitana ArgR and T. maritima putative regulatory proteins. Lane 1 -without protein; 
lanes 2-5 contain 12, 24, 48, and 96 nM operator DNA. His-tagged purified proteins were probed to labeled operator DNA at $37^{\circ} \mathrm{C}$ for 30 min and subjected to electrophoresis on a $2 \%$ agarose gel. ArgR binding was carried out in the presence of L-arginine in both binding and running buffers.

\section{Discussion}

The development of alternative expression modules remains an important challenge in expanding CFPS for biomedical applications and high-throughput proteomic studies. A retrospective evaluation of CFPS approaches highlights the importance of improving the transcriptional machinery to produce various functionally active proteins [38]. The efficiency of transcription determines the processing of mRNA by the rate-limiting step for CFPS.

In our study, several approaches were tested to improve the transcription process and increase cell-free production of different proteins. We demonstrated that the G. stearothermophilus pargC promoter (see Figure 1) provides rather high gene expression in cell extracts prepared from E. coli BL21 (DE3). The strong promoter pargC enhances up to 1.8-fold the target protein yield in cell-free extracts prepared from bacteria, in which the cloned genes coding for $\alpha, \beta, \beta^{\prime}$ and $\omega$ subunits of $E$. coli RNA polymerase are simultaneously coexpressed from two compatible plasmids. The limited capacity of the coexpressed RNA polymerase subunits to support the high transcription of the target amaA gene from the strong parg $C$ promoter could be related to the insolubility of $\beta$ and $\beta^{\prime}$ subunits and/or to an insufficient quantity of a major $\sigma^{70}$ factor critical for the assembly of a greater amount of a functionally active holoenzyme.

We have shown that the extension of the amaA gene, by 100-200 bp segment located downstream, can substantially improve the pargC-mediated expression from linear DNAs, suggesting the participation of a stem-loop structure within the corresponding $3^{\prime}$ UTR. Indeed, such a structure of the T7 transcription terminator remarkably enhances the amaA gene expression from a linear template, leading to a protein yield close to that observed with circular plasmid DNA. Similar results have been obtained for pT7-mediated gene expression $[39,40]$. Therefore, linear DNAs carrying potential stem-loop forming sequences at the end of the coding region or within $3^{\prime}$ UTR can contribute to enhancing CFPS independently of the nature of the promoter used.

The difference in the endo- and exo-ribonuclease activities of individual enzymes determines the ability of the transcriptional degradasome to provide different levels of functionally active mRNAs in cells. The diversity and complexity of mechanisms controlling the quantity and quality of mRNAs, which vary in their length, primary sequence, and secondary structure, make the development of a universal cell-free system that ensures the high production of numerous proteins in parallel reactions a difficult task. RNase E appears to play a major role in mRNA decay in the bacterial cytoplasm. A 2 nt deletion of the $r n a E$ gene (smbB131 mutation renamed rnaE131) causes a premature stop of translation at the 584th codon of RNase E, which stabilizes mRNAs susceptible to hydrolysis by RNase E [7]. Consequently, E. coli BL21 Star (DE3) cells harboring the rnaE131 mutation produce more proteins from RNase E sensitive messages [34]. The preservation of mRNA degradation has been also shown in RNase E-deficient cell extracts of E. coli [41]. However, our data indicate that the synthesis of bacterial AmaA, GroES and RraA or human NAT1 and NAT2 proteins is not increased in the rnaE131 cell-free extracts of E. coli BL21 Star (DE3). In this context, it is worth mentioning that RNA decay and processing appear to occur at specific cell membrane sites that are in contact with a multiprotein degradosome complex via RNase E [42]. During the preparation of S30 extracts, the cell membrane is discarded; therefore, the degradosome complex might be dissociated and consequently, RNase E would not be able to fully accomplish degradosome-related functions. Despite remarkable progress in improving cell-free transcription for protein synthesis, investigations in this direction remain quite current [43].

To assess the action of RNase I endoribonuclease on the stability of mRNAs in a cellfree system, we constructed rna::Tn10-deficient mutants of the E. coli BL21 strain. RNase I is 
processed from a precursor protein by cleavage of a leader peptide followed by exporting a $27 \mathrm{kDa}$ enzyme into the periplasm of Gram-negative bacteria [10]. Our data suggest that the liberated enzyme is retained in S30 extracts; therefore, both prokaryotic and eukaryotic genes are better expressed in the extracts prepared from RNase-I-deficient $r n a^{-}$mutants rather than RNase-I-proficient $r n a^{+}$strains. Obviously, the application of new extracts from E. coli BL21 rna- mutant cells, which lack the periplasmic EDTA-tolerant RNase I, is a radical way to prevent a rapid decay of messages and thus to improve the performance of cell-free protein production promoted by strong bacterial or phage transcription signals.

We have previously shown that cell-free synthesized proteins allow simultaneous and rapid assessment of binding to many promoters, thereby experimentally confirming the accuracy of in silico prediction of strong promoters in the genome of the hyperthermophilic bacterium T. maritima [44]. This study shows that diversifying and integrating bacterial and/or phage transcription signals into cell-free extracts can significantly improve the efficiency of CFPS and increase the yield/production of both prokaryotic and eukaryotic proteins. Moreover, CFPS can overcome the major obstacles faced by hard-toexpress proteins in bacterial cells, such as transmembrane proteins, toxic proteins, and aggregation-prone proteins or proteins from bacteria maintained in nongrowing laboratory conditions $[45,46]$.

\section{Conclusions}

Cell-free protein production and its use to study molecular interactions is an alternative approach to cell-based methods commonly employed in different fields of biology. Cell-free extracts from prokaryotic cells have been developed to optimize the conditions for specific protein expression enabling target binding and identification efforts, as well as uncovering novel enzymatic activities. Considering the difficulties of protein production in cells, cell-free systems are being increasingly used to generate proteome scale tools for biomedical research. The advantageous characteristics of cell-free systems described in this and other studies open attractive opportunities for high-throughput and multiplexed screening methods adapted to CFPS, such as protein, antibody and small molecule microarrays, to identify and study new therapeutic agents for various human diseases.

Supplementary Materials: The following are available online at https: / www.mdpi.com/article / 10.3390/biotech10040024/s1, Table S1: Oligonucleotide primers used for PCR amplification of T. maritima genes, Table S2: Oligonucleotide primers used for PCR amplification of promoter-operator regions, Figure S1: Purification of the core enzyme RNA polymerase from the soluble fraction of E. coli extracts, Figure S2: Subunits $\alpha, \beta, \beta^{\prime}$ and $\omega$ of E. coli RNA polymerase in inclusion bodies after purification using the His-tagged $\alpha$ subunit.

Author Contributions: Conceptualization and supervision, F.M. and V.S.; investigation, M.S., S.R., G.Y. and M.L.; validation, M.S. and V.S.; writing-original draft preparation, M.S. and V.S.; writing-review and editing, V.S. and G.Y. All authors have read and agreed to the published version of the manuscript.

Funding: This study was supported by the ProtNeteomix.

Institutional Review Board Statement: Not applicable.

Informed Consent Statement: Not applicable.

Data Availability Statement: The data are available upon request from the authors.

Acknowledgments: We greatly acknowledge Marc Dreyfus for the E. coli K12 DK533 strain.

Conflicts of Interest: S.R. and F.M. were employees of ProtNeteomix. M.S., G.Y., M.L. and V.S. have no conflict of interest. 


\section{References}

1. Nirenberg, M.W.; Matthaei, J.H. The dependence of cell-free protein synthesis in E. coli upon naturally occurring or synthetic polyribonucleotides. Proc. Natl. Acad. Sci. USA 1961, 47, 1588-1602. [CrossRef]

2. Golomb, M.; Chamberlin, M. Characterization of T7-specific ribonucleic acid polymerase. IV. Resolution of the major in vitro transcripts by gel electrophoresis. J. Biol. Chem. 1974, 249, 2858-2863.

3. Hui, M.P.; Foley, P.L.; Belasco, J.G. Messenger RNA degradation in bacterial cells. Annu. Rev. Genet. 2014, 48, 537-559. [CrossRef]

4. Bechhofer, D.H.; Deutscher, M.P. Bacterial ribonucleases and their roles in RNA metabolism. Crit. Rev. Biochem. Mol. Biol. 2019, 54, 242-300. [CrossRef] [PubMed]

5. Catherine, C.; Lee, K.H.; Oh, S.J.; Kim, D.M. Cell-free platforms for flexible expression and screening of enzymes. Biotechnol. Adv. 2013, 31, 797-803. [CrossRef] [PubMed]

6. Cole, S.D.; Miklos, A.E.; Chiao, A.C.; Sun, Z.Z.; Lux, M.W. Methodologies for preparation of prokaryotic extracts for cell-free expression systems. Synth. Syst. Biotechnol. 2020, 5, 252-267. [CrossRef]

7. Kido, M.; Yamanaka, K.; Mitani, T.; Niki, H.; Ogura, T.; Hiraga, S. RNase E polypeptides lacking a carboxyl-terminal half suppress a mukB mutation in Escherichia coli. J. Bacteriol. 1996, 178, 3917-3925. [CrossRef] [PubMed]

8. Subbarayan, P.R.; Deutscher, M.P. Escherichia coli RNase M is a multiply altered form of RNase, I. RNA 2001, 7, $1702-1707$.

9. Kennell, D. Processing endoribonucleases and mRNA degradation in bacteria. J. Bacteriol. 2002, 184, 4645-4657. [CrossRef]

10. Zhu, L.; Gangopadhyay, T.; Padmanabha, K.P.; Deutscher, M.P. Escherichia coli RNA gene encoding RNase I: Cloning, overexpression, subcellular distribution of the enzyme, and use of a rna deletion to identify additional RNases. J. Bacteriol. 1990, 172, 3146-3151. [CrossRef] [PubMed]

11. Snapyan, M.; Lecocq, M.; Guével, L.; Arnaud, M.C.; Ghochikyan, A.; Sakanyan, V. Dissecting DNA-protein and protein-protein interactions involved in bacterial transcriptional regulation by a sensitive protein array method combining a near-infrared fluorescence detection. Proteomics 2003, 3, 647-657. [CrossRef]

12. Yeretssian, G.; Lecocq, M.; Lebon, G.; Hurst, H.C.; Sakanyan, V. Competition on nitrocellulose-immobilized antibody arrays: From bacterial protein binding assay to protein profiling in breast cancer cells. Mol. Cell. Proteom. 2005, 4, 605-617. [CrossRef]

13. Dimova, D.; Weigel, P.; Takahashi, M.; Marc, F.; Van Duyne, G.D.; Sakanyan, V. Thermostability, oligomerization and DNAbinding properties of the regulatory protein ArgR from the hyperthermophilic bacterium Thermotoga Neapolitana. Mol. Gen. Genet. 2000, 263, 119-130. [CrossRef]

14. Nelson, K.E.; Clayton, R.A.; Gill, S.R.; Gwinn, M.L.; Dodson, R.J.; Haft, D.H.; Hickey, E.K.; Peterson, J.D.; Nelson, W.C.; Ketchum, K.A.; et al. Evidence for lateral gene transfer between Archaea and Bacteria from genome sequence of Thermotoga maritima. Nature 1999, 399, 323-329. [CrossRef] [PubMed]

15. Lee, K.; Zhan, X.; Gao, J.; Qiu, J.; Feng, Y.; Meganathan, R.; Cohen, S.N.; Georgiou, G. RraA, a protein inhibitor of RNase E activity that globally modulates RNA abundance in E. coli. Cell 2003, 114, 623-634. [CrossRef]

16. Sim, E.; Abuhammad, A.; Ryan, A. Arylamine N-acetyltransferases: From drug metabolism and pharmacogenetics to drug discovery. Br. J. Pharmacol. 2014, 171, 2705-2725. [CrossRef] [PubMed]

17. Sakanyan, V.; Charlier, D.; Legrain, C.; Kochikyan, A.; Mett, I.; Pierard, A.; Glansdorff, N. Primary structure, partial purification and regulation of key enzymes of the acetyl cycle of arginine biosynthesis in Bacillus stearothermophilus: Dual function of ornithine acetyltransferase. J. Gen. Microbiol. 1993, 139, 393-402. [CrossRef]

18. Sakanyan, V.; Desmarez, L.; Legrain, C.; Charlier, D.; Mett, I.; Kochikyan, A.; Savchenko, A.; Boyen, A.; Falmagne, P.; Piérard, A.; et al. Gene cloning, sequence analysis, purification, and characterization of a thermostable aminoacylase from Bacillus stearothermophilus. Appl. Environ. Microbiol. 1993, 59, 3878-3888. [CrossRef]

19. Zheng, M.; Cooper, D.R.; Grossoehme, N.E.; Yu, M.; Hung, L.W.; Cieslik, M.; Derewenda, U.; Lesley, S.A.; Wilson, I.; Giedroc, D.P.; et al. Structure of Thermotoga maritima TM0439: Implications for the mechanism of bacterial GntR transcription regulators with Zn2+-binding FCD domains. Acta Crystallogr. D Biol. Crystallogr. 2009, 65, 356-365. [CrossRef] [PubMed]

20. Karaivanova, I.M.; Weigel, P.; Takahashi, M.; Fort, C.; Versavaud, A.; Van Duyne, G.; Charlier, D.; Hallet, J.N.; Glansdorff, N.; Sakanyan, V. Mutational analysis of the thermostable arginine repressor from Bacillus stearothermophilus: Dissecting residues involved in DNA binding properties. J. Mol. Biol. 1999, 291, 843-855. [CrossRef] [PubMed]

21. Rosner, J.L. Formation, induction and curing of bacteriophage P1 lysogens. Virology 1972, 48, 679-689. [CrossRef]

22. Srivastava, S.K.; Cannistraro, V.J.; Kennell, D. Broad-specificity endoribonucleases and mRNA degradation in Escherichia coli. J. Bacteriol. 1992, 174, 56-62. [CrossRef]

23. Borukhov, S.; Goldfarb, A. Recombinant Escherichia coli RNA polymerase: Purification of individually overexpressed subunits and in vitro assembly. Protein Expr. Purif. 1993, 4, 503-511. [CrossRef]

24. Zubay, G. In vitro synthesis of protein in microbial systems. Annu. Rev. Genet. 1973, 7, 267-287. [CrossRef]

25. Nevin, D.E.; Pratt, J.M. A coupled in vitro transcription-translation system for the exclusive synthesis of polypeptides expressed from the T7 promoter. FEBS Lett. 1991, 291, 259-263. [CrossRef]

26. Kim, D.-M.; Swartz, J.R. Prolonging cell-free protein synthesis with a novel ATP regeneration system. Biotechnol. Bioeng. 1999, 66, 180-188. [CrossRef]

27. Batisse, N. Étude Génétique d'enzymes Responsables de la Résolution des Acides Aminés de la Série L à Partir de Dérivés N-Substitués chez la Bactérie Thermophile Bacillus stearothermophilus. Ph.D. Thesis, University of Nantes, Nantes, France, 1997. 
28. Ghochikyan, A.; Karaivanova, I.M.; Lecocq, M.; Vusio, P.; Arnaud, M.C.; Snapyan, M.; Weigel, P.; Guével, L.; Buckle, M.; Sakanyan, V. Arginine operator binding by heterologous and chimeric ArgR repressors from Escherichia coli and Bacillus stearothermophilus. J. Bacteriol. 2002, 184, 6602-6614. [CrossRef]

29. Savchenko, A.; Weigel, P.; Dimova, D.; Lecocq, M.; Sakanyan, V. The Bacillus stearothermophilus argCJBD operon harbours a strong promoter as evaluated in Escherichia coli cells. Gene 1998, 212, 167-177. [CrossRef]

30. Higgins, C.F.; McLaren, R.S.; Newbury, S.F. Repetitive extragenic palindromic sequences, mRNA stability and gene expression: Evolution by gene conversion? Gene 1988, 72, 3-14. [CrossRef]

31. Régnier, P.; Hajnsdorf, E. Decay of mRNA encoding ribosomal protein S15 of Escherichia coli is initiated by an RNase E-dependent endonucleolytic cleavage that removes the 3' stabilizing stem and loop structure. J. Mol. Biol. 1991, 217, 282-292. [CrossRef]

32. Studier, F.W.; Rosenberg, A.H.; Dunn, J.J.; Dubendorff, J.W. Use of T7 RNA polymerase to direct expression of cloned genes. Methods Enzymol. 1990, 185, 60-89.

33. Köhrer, C.; Mayer, C.; Grobner, P.; Piendl, W. Use of T7 RNA polymerase in an optimized Escherichia coli coupled in vitro transcription-translation system. Application in regulatory studies and expression of long transcription units. Eur. J. Biochem. 1996, 236, 234-239.

34. Lopez, P.J.; Marchand, I.; Joyce, S.A.; Dreyfus, M. The C-terminal half of RNase E, which organizes the Escherichia coli degradosome, participates in mRNA degradation but not rRNA processing in vivo. Mol. Microbiol. 1999, 33, 188-199. [CrossRef] [PubMed]

35. Tong, S.; Porco, A.; Isturiz, T.; Conway, T. Cloning and molecular genetic characterization of the Escherichia coli gntR, gntK, and gntU genes of GntI, the main system for gluconate metabolism. J. Bacteriol. 1996, 178, 3260-3269. [CrossRef]

36. Song, S.; Park, C. Utilization of D-ribose through D-xylose transporter. FEMS Microb. Lett. 1998, 163, $255-261$.

37. Oehler, S. Feedback regulation of Lac repressor expression in Escherichia coli. J. Bacteriol. 2009, 191, 5301-5303. [CrossRef] [PubMed]

38. Dondapati, S.K.; Stech, M.; Zemella, A.; Kubick, S. Cell-Free Protein Synthesis: A Promising Option for Future Drug Development. BioDrugs 2020, 34, 327-348. [CrossRef] [PubMed]

39. Ahn, J.H.; Chu, H.S.; Kim, T.W.; Oh, I.S.; Choi, C.Y.; Hahn, G.H.; Park, C.G.; Kim, D.M. Cell-free synthesis of recombinant proteins from PCR-amplified genes at a comparable productivity to that of plasmid-based reactions. Biochem. Biophys. Res. Commun. 2005, 338, 1346-1352. [CrossRef]

40. Michel-Reydellet, N.; Woodrow, K.; Swartz, J. Increasing PCR fragment stability and protein yields in a cell-free system with genetically modified Escherichia coli extracts. J. Mol. Microbiol. Biotechnol. 2005, 9, 26-34. [CrossRef]

41. Hahn, G.H.; Kim, D.M. Production of milligram quantities of recombinant proteins from PCR-amplified DNAs in a continuousexchange cell-free protein synthesis system. Anal. Biochem. 2006, 335, 151-153. [CrossRef]

42. Liou, G.-G.; Jane, W.-N.; Cohen, S.N.; Lin, N.-S.; Lin-Chao, S. RNA degradosomes exist in vivo in Escherichia coli as multicomponent complexes associated with the cytoplasmic membrane via the $\mathrm{N}$-terminal region of ribonuclease E. Proc. Natl. Acad. Sci. USA 2001, 98, 63-68. [CrossRef]

43. Hibi, K.; Amikura, K.; Sugiura, N.; Masuda, K.; Ohno, S.; Yokogawa, T.; Ueda, T.; Shimizu, Y. Reconstituted cell-free protein synthesis using in vitro transcribed tRNAs. Commun. Biol. 2020, 3, 350. [CrossRef]

44. Dekhtyar, M.; Morin, A.; Sakanyan, V. Triad pattern algorithm for predicting strong promoter candidates in bacterial genomes BMC Bioinform. 2008, 9, 233. [CrossRef] [PubMed]

45. Failmezger, J.; Rauter, M.; Nitschel, R.; Kraml, M.; Siemann-Herzberg, M. Cell-free protein synthesis from non-growing, stressed Escherichia coli. Sci. Rep. 2017, 7, 16524. [CrossRef] [PubMed]

46. Chiba, C.H.; Knirsch, M.C.; Azzoni, A.R.; Moreira, A.R.; Stephano, M.A. Cell-free protein synthesis: Advances on production process for biopharmaceuticals and immunobiological products. Biotechniques 2020, 70, 2. [CrossRef] 